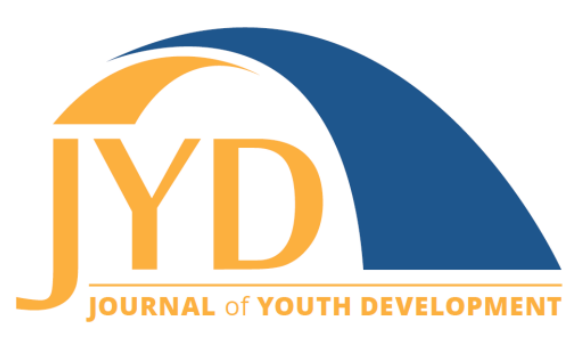

http://jyd. pitt. edu/ | Vol. 14 Issue 3 DOI 10.5195/jyd.2019.660 | ISSN 2325-4017 (online)

\title{
Social-Emotional Learning and Evaluation in After-School Care: A Working Model
}

\author{
Dana Minney \\ Texas State University \\ dlminney@gmail.com \\ Jaime Garcia \\ Extend-A-Care \\ jgarcia@eackids.org \\ Joan Altobelli \\ Extend-A-Care \\ jaltobelli@eackids.org
}

\section{Norma Perez-Brena}

Texas State University

norma.perez-brena@txstate.edu

\section{Elizabeth Blunk}

Texas State University

eb03@txstate.edu

\section{Abstract}

Social-emotional competence in children is an important area in which to develop and improve effective programs and evaluation. Research shows a positive association between social-emotional learning (SEL) and improvements in students' conduct, social behavior, and school engagement as well as decreases in high-risk behaviors such as taking drugs, smoking and aggression. Extensive research points to the positive benefits of successful SEL curriculum in schools, but less research exists on SEL implementation in after-school care settings. Since social-emotional competence is correlated with higher positive effects and a decrease of negative effects in the social, behavioral, and academic outcomes of children exposed to these programs, more research is needed on the most effective format and environment for implementation. The purpose of this article is to review this research, and report the results of an evaluation comparing pre- and post-program survey data from children ( $\mathrm{n}=125$; age range $=4-11$ years) attending an after-school program that has incorporated an SEL curriculum. Results showed

(cc) EY New articles in this journal are licensed under a Creative Commons Attribution 4.0 License. This journal is published by the University Library System, University of Pittsburgh and is cosponsored by the University of Pittsburgh Press. The Journal of Youth Development is the official peer-reviewed publication of the National Association of Extension 4-H Agents and the National AfterSchool Association. 


\section{Social-Emotional Learning}

significant increases in two SEL competencies: empathy and self-soothing. The advantages to providing both SEL instruction and evaluation in after-school care settings in addition to schools is also explored.

Key words: social-emotional learning, after-school programs, program evaluation, SEL curriculum, selfsoothing

\section{Background}

Social-emotional Learning (SEL), the process through which children develop social and emotional competence, has been found to effectively reduce the likelihood of aggression, drug use, and other high-risk behaviors, as well as improve self-control, emotional regulation, and academic performance and increase likelihood of graduation (Belfield et al., 2015; Domitrovich, Durlak, Staley, \& Weissberg, 2017; Durlak, Weissberg, Dymnicki, Taylor, \& Schellinger, 2011). Research has found school-based SEL programs (i.e. school- and district-wide adoption of SEL curriculum and practices) effectively increase students' school engagement and success (Durlak et al., 2011). Although school-based SEL programs significantly improved students' positive social behaviors and reduced high-risk behaviors, there were problems with school implementation (Durlak et al., 2011), which moderated the program outcomes, meaning they weakened the relationship between intervention and outcome (Domitrovich et al., 2017; Durlak et al., 2011; Durlak \& DuPre, 2008).

Research in the last decade revealed the potential of after-school programs (ASPs) to provide children with supplemental exposure to SEL (Durlak, Weissberg, \& Pachan, 2010). ASPs can deliver SEL without the problems often faced by traditional school settings like curricular, policy, and administrative demands (Hurd \& Deutsch, 2017). Curriculum in schools is generally determined by district policy with academic concerns taking precedence, whereas curriculum and activities in ASPs are not. Although there is no widely used approach in measuring SEL program impact in ASPs (Gullotta, 2015), this paper aims to describe an ASP (Extend-A-Care) that designed, implemented, and evaluated their curriculum using pre- and post-program data, in the hope that it will lead to a path for others to develop and implement their own SEL curriculum and highlight important points to consider when doing so. 


\section{Social-Emotional Learning}

\section{Literature Review}

\section{Social-Emotional Learning}

The Collaborative for Academic, Social, and Emotional Learning ([CASEL], 2012) describes SEL as the process through which children and adolescents acquire and effectively apply the knowledge, attitudes, and skills necessary to understand and manage emotions, set and achieve positive goals, feel and show empathy for others, establish and maintain positive relationships, and make responsible decisions. Further, CASEL operationalized SEL as five competencies:

- self-awareness: the ability to assess personal feelings accurately;

- self-management: the ability to handle one's emotions and behavior productively and self-soothe;

- social awareness: the ability to take others' perspectives, empathy;

- relationship and social skills: the ability to promote positive and effective exchanges with others; and

- responsible decision-making: analyzing social situations and problems, and setting prosocial goals.

SEL programs have been the focus of much research and intervention work because of the link to positive outcomes and its cost-effectiveness. For example, in two meta-analyses on the impact of SEL programs (one on school-based programs and one on out-of-school programs), children showed improved academic performance, enhanced positive attitudes and social behavior, and decreased emotional distress (Durlak et al., 2011; Durlak et al., 2010). SEL programs were also found to increase the likelihood of children's positive life outcomes, such as higher likelihood of high school graduation, more workplace success, and lower rates of incarceration (Moffitt et al., 2011). A cost-benefit analysis of six specific SEL programs (4Rs, Positive Action, Life Skills Training, Second Step, Responsive Classroom, and Swedish Social and Emotional Training) found an average return of $\$ 11$ for every dollar invested (Belfield et al., 2015; Rimm-Kaufman \& Hulleman, 2015).

SEL programs are most frequently implemented in school settings (Gullotta, 2015; Durlak et al., 2010) which may consist of weekly or bi-weekly lessons delivered by teachers in the school, dealing with topics like identifying emotions, expressing feelings, bullying prevention, and managing one's behavior (Smith \& Low, 2013). The average duration of each lesson is 40 minutes and teachers initially receive two or more days of training on implementation (Sheard, Ross, \& Cheung, 2012). Despite the clear evidence of the benefit of SEL, and the positive 


\section{Social-Emotional Learning}

regard many researchers and educators have for it (Coryn, Spybrook, Evergreen, \& Blinkiewicz, 2009; Hurd \& Deutsch, 2017), there are several problems preventing high quality implementation of SEL in schools. The most commonly mentioned problems are lack of funding needed to provide sufficient training for teachers (Domitrovich et al., 2017; Elias, O'Brien, \& Weissberg, 2006), lack of school readiness to adopt SEL best practices (Elias et al., 2015; Patti, Senge, Madrazo, \& Stern, 2015), and district policies prioritizing student's academic outcomes over SEL (Elias et al., 2015; Gullotta, 2015).

Schools may face several of these interrelated problems simultaneously. For example, when state or district policies prioritize students' academic outcomes over students' SEL, it may be because they mistakenly assume SEL displaces instruction that more directly impacts academic performance (Elias et al., 2015). In reality SEL was shown to improve student's academic scores, but when school and district leaders chose teacher training that focused on helping teachers learn how to raise students' academic test scores, the funding needed for teachers' SEL training was unavailable (Domitrovich et al., 2017). In turn, those schools were not able to adopt SEL best practices such as making SEL programs school-wide, rather than for just a few classrooms or individually selected students (Mart, Weissberg, \& Kendziora, 2015). District policy change is required to increase the adoption of SEL best practices in schools (e.g., provide funding for teacher training in $\mathrm{SEL}$ ), but is unlikely if there is an existing policy to prioritize academic scores (Elias et al., 2015; Patti et al., 2015).

\section{Benefits of Social-Emotional Learning in After-School Programs}

ASPs offer activities for children and adolescents outside of normal school hours under the supervision of adults (Durlak et al., 2010). In the United States today, nearly 1 in 4 families has a child enrolled in an after-school program and this number has risen from 6.5 million children in 2004 to 10.4 million children in 2014 (Afterschool Alliance, 2014). While the focus of ASPs began as a means to provide supervision to children, there has been a growing push to provide social enrichment and skill-building (Gullotta, 2015). This shift was partly due to a study that showed most delinquent behavior occurred between 3 and 6 p.m., when children had unsupervised out-of-school-time (Gottfredson, Gerstenblith, Soulé, Womer, \& Lu, 2004). In response, developmental scientists introduced the concept of Positive Youth Development (PYD), which then began to inform some ASPs like Big Brothers/Big Sisters and The PATHS Project (Laughlin, 2013). These were aimed at fostering youths' personal and social development and enhancing new skills and personal talents through a range of adult-supervised activities (Durlak et al., 2010; Lerner, Lerner, Urban, \& Zaff, 2016; Catalano, Berglund, Ryan, 


\section{Social-Emotional Learning}

Lonczak, \& Hawkins, 2004). With ASPs now seen as places for enrichment-where children may attend a program emphasizing social skills, technology, or art-they have tremendous potential to positively impact children's lives. In particular, ASPs can be places where SEL curricula can be provided while bypassing some of the barriers that traditional schools face (Hurd \& Deutsch, 2017).

Research on effective implementation of SEL programs showed consistent and sequenced lessons, continuous training for staff, and a campus-wide adoption of SEL works best (Durlak, Domitrovich, Weissberg, \& Gullotta, 2015; Elias, O'Brian, \& Weissberg, 2006). ASPs can more easily comply with these practices, partly because they determine their own policies, unlike schools. Therefore, if an ASP chooses to emphasize SEL as Extend-A-Care has done, they can, and the staff training will reflect this priority. Also, facility-wide adoption of SEL and commitment to training all staff in their social-emotional development are necessary for SEL to be most effective (Elias et al., 2006). Schools may have a harder time sending a unified message (as has been called for in the literature) and placing SEL training as a top priority than ASPs (Elias et al., 2006). Schools are bound by academic expectations from the district, which leads to school resources and trainings focusing on producing academic results, rather than SEL (Elias et al., 2015). Therefore, local decision-making and administration make it easier for some ASPs to present a unified vision regarding SEL to staff and to implement campus-wide adoption (Domitrovich et al., 2017).

Evidence from a meta-analysis showed children in ASP programs that promoted personal and social skills reported an $11 \%$ increase in their academic achievement (Durlak et al., 2010). ASPs can also complement and reinforce SEL instruction that is provided in traditional school settings. In fact, research suggested school curriculum should be integrated with ASPs as much as possible for SEL to work to its maximum potential (Greenberg et al., 2003).

Despite the benefits of SEL in ASP's, there are challenges to high quality delivery (Gullotta, 2015). SEL curricula specifically designed for use in ASPs are not widely available, and are difficult to design (see the Incredible Years Program for one exception; Webster-Stratton \& Herman, 2010). School-based SEL curricula is not transferable to ASPs (where multiple grades could be combined) because school-based lessons are usually age- or grade-specific (Belfield et al., 2015; Gullota, 2015). Extend-A-Care (EAC) is one ASP that has worked to overcome the challenges. 


\section{Social-Emotional Learning}

\section{Social-Emotional Learning at Extend-A-Care}

Extend-A-Care (EAC)-the ASP highlighted in this paper-aims to provide a context where positive youth development can occur. It started nearly 50 years ago with one location and has continually improved and expanded its service delivery. Now over 3,500 children attend EAC's school-year program and 900 children attend their summer program. There are over 80 locations and 380 staff members. EAC's mission is to enhance cognitive, social, and physical development of children, and assist working families and communities by providing enriching, affordable, licensed child care. One primary objective is to reduce the number of children falling victim to or committing crimes due to inadequate supervision by offering a safe and enriching environment for children. EAC is highlighted here because it provides an example of how an ASP can address the challenges noted above (i.e., limited access to high-quality SEL curricula).

In 2010, CASEL launched a national initiative where eight school districts in select cities across the United States adopted district-wide SEL curricula (Mart et al., 2015). Since many of EAC's locations served children in one of the selected districts, EAC administrators decided to introduce an SEL curriculum into their programs as well. EAC's Operations Director and Curriculum Director collaborated with the school district allowing them to share the SEL materials purchased by the district. By modifying the school district's SEL program, EAC created lessons that provided reinforcement and continuity with the SEL the children were exposed to at school, thereby increasing the likelihood of stronger effects and more sustainable change (Tolan, Guerra, \& Kendall, 1995). EAC found a proactive way to overcome the obstacle of limited availability of literature on SEL curriculum specifically designed for ASPs (Mart et al., 2015).

District-level input was identified as a challenge to SEL implementation in schools because the district's priorities tend to dictate the training agenda, rather than the individual school (Mart et al., 2015). For example, if a district adopts an initiative to improve standardized test results, district leaders will choose training that is believed to reach this goal (Belfield et al., 2015; Hurd \& Deutsch, 2017; Mart et al., 2015). Conversely, EAC administrators are able to determine the agenda for staff development trainings independent of external policies. ASPs are not held responsible for children's grades or test scores, so staff development can reflect the mission and values of the individual facility. In EAC's case this means staff training focuses on developing the social-emotional development of group leaders (as research has recommended), behavior management, and mindfulness (Jennings \& Frank, 2015). 


\section{Social-Emotional Learning}

Researcher Gullotta (2015) found one of the important qualities of successful SEL in ASPs is to hold staff accountable for adhering to implementation procedures. EAC's staff are expected to have high accountability and commitment to the program's values and standards, including SEL practices and expectations. EAC does this through multiple channels (i.e. yearly evaluations, monthly and quarterly quality reports, monthly trainings, and daily curriculum lessons). Uniform policies for daily activities schedule and SEL center setup as well as the streamlined leadership at EAC (from executive director, operations director, area director, site supervisor to group leader), allowed for easily monitored implementation. EAC's organizational strengths, ability to collaborate with educational professionals like the school district and national SEL experts, and high commitment to children's social-emotional development allowed them to overcome the challenges preventing SEL delivery.

\section{Evaluation Question}

Emotions and social relationships can either support or hinder a child's development. SEL program impact research has shown time and money invested in improving SEL programs is well-spent (Belfield et al., 2015; Durlak et al., 2011). Research also shows when SEL lessons learned out-of-school are consistent with lessons learned in school the child benefits (Hurd \& Deutsch, 2017). Therefore, continuing to improve SEL delivery in after-school care, as well as evaluate the impact of SEL curriculum is crucial for children's development and for ASP design. The purpose of this evaluation was to determine if there would be changes in SEL, as measured by self-management, self-awareness, and social awareness, in children who participated in EAC's SEL curriculum.

\section{Method}

\section{Participants}

The researcher randomly chose six (out of 80) EAC sites for the curriculum evaluation by numbering each site and using a random number generator. A total of 191 children from all six sites (with varying numbers from each site) completed a pre- or post-program survey, but only 125 completed both. Data from the 66 children who completed only one or the other of the surveys were omitted. The children ranged in age from 4 to 11 years old $(M=7.25, S D=2.0)$. Gender was evenly distributed between males and females. 


\section{Social-Emotional Learning}

The study was approved by the Texas State University's Institutional Review Board (IRB). Informed consent was obtained from most of the parents and the children without parental consent were omitted from the final analysis and report. No information on ethnicity of the children was obtained, in compliance with procedures approved by the IRB waiver.

\section{Procedures}

\section{SEL CURriculum}

EAC's Operations Director and Curriculum Director worked together to create the SEL curriculum with the initial goal of decreasing bullying and conflict through children understanding how to regulate their emotions and have more self-control. Lesson content was chosen from a variety of sources (including materials loaned by the SEL department of a school district) and modified for ASP use. Taking the initiative to reach out to local school district SEL departments for guidance, training, and resources was important in providing consistent language children could understand. Partnering with the school district also gave EAC access to district-wide teacher training materials including Peace Path (Abadesco \& Savage, 2015) and the Mindfulness Revolution training (Boyce, 2011), as well as Second Step curriculum (classroom-based social skills curriculum with specific lessons for each grade; Jennings \& Frank, 2015), and the AntiDefamation League's No Place for Hate. This content was then put into a 5-day guide and distributed to all group leaders at the beginning of each week, along with a packet of any needed materials corresponding with the lessons. SEL lessons occurred Monday through Friday for 10 to 15 minutes and were conducted by group leaders in segments called, "group meetings." At EAC children are divided by age into groups of 12 to 17 children. Each group has a group leader who is responsible for the activities of their group every day, and group leaders are designated by a site supervisor who oversees all groups and group leaders at each location.

SEL instruction occurred in one group of children at a time with children being invited to sit in a circle or around a "Feelings Rug" to learn how to routinely calm themselves down when upset, to empathize with others, and about their own emotions. For example, children viewed pictures of faces displaying various emotions, and identified the face representing their current feelings, then shared the reason for feeling that way. The SEL curriculum aimed to improve children and adolescents' understanding of emotions, and create and maintain positive relationships.

EAC trained more than 380 staff members by including SEL purpose and techniques in the new hire training and follow-up annual trainings that lasted approximately 45 minutes. Each new staff member had a 30-minute observation period on group meeting time prior to starting 


\section{Social-Emotional Learning}

employment. In addition, EAC conducted ongoing trainings once a month throughout the year for site leaders and provided them with approximately five additional hours of SEL training.

\section{Evaluation \& Data Collection}

The first phase of the evaluation occurred a few weeks after beginning the school year. Children gave assent prior to data collection. Parents gave retroactive consent to allow the researchers to publish data that was gathered through these evaluation activities. An SEL self-report survey based on the CASEL model (CASEL, 2012) was developed by EAC directors and the researcher with an emphasis on self-awareness, self-management, and social awareness. A student intern at each chosen EAC site handed out the pre-program surveys to the children 8 years and older after a short explanation. These children filled out surveys themselves. Because of younger children's less-developed literacy skills (Borgers, Hox, \& Sikkel, 2003) children between the ages of 4 and 7 were individually interviewed by a student intern, who was trained by the graduate student researcher. The post-program surveys were administered in April, a few weeks prior to the end of school in the same manner.

\section{Measure.}

The CASEL model served as the basis for designing the evaluation tool to assess the constructs of self-management (two items), social awareness (two items), and self-awareness (one item; Table 1). 


\section{Social-Emotional Learning}

Table 1. Evaluation Questions and Response Choices

\begin{tabular}{|l|l|l|}
\hline Competency & Question & Response option \\
\hline Self-management & $\begin{array}{l}\text { It is (blank) to calm myself down when I'm feeling } \\
\text { upset. }\end{array}$ & $\begin{array}{l}1=\text { Very Hard to } \\
4=\text { Very Easy }\end{array}$ \\
\hline & $\begin{array}{l}\text { Can you think of three ways to calm yourself down } \\
\text { when you are upset? }\end{array}$ & $\begin{array}{l}\text { (Open-ended } \\
\text { question) }\end{array}$ \\
\hline Social awareness & $\begin{array}{l}\text { It is (blank) for me to know what people might be } \\
\text { feeling by the look on their face. }\end{array}$ & $\begin{array}{l}1=\text { Very Hard to } \\
4=\text { Very Easy }\end{array}$ \\
\hline & $\begin{array}{l}\text { If I accidentally hurt my friend's feelings, it is (blank) } \\
\text { to figure out what to do to make them feel better. }\end{array}$ & $\begin{array}{l}1=\text { Very Hard to } \\
4=\text { Very Easy }\end{array}$ \\
\hline Self-awareness & $\begin{array}{l}\text { It is (blank) for me to think about what might } \\
\text { happen before I decide what to do. }\end{array}$ & $\begin{array}{l}1=\text { Very Hard to } \\
4=\text { Very Easy }\end{array}$ \\
\hline
\end{tabular}

\section{Results}

Pre- and post-program scores were compared using paired samples $t$-tests in SPSS to assess changes in self-management, social awareness, and self-awareness. Although all participating children [ $n=191$ ] provided a pre- or post- program survey, only 125 children completed both surveys and were included in our analyses. The number of paired responses is listed next to each question because the number of respondents varied depending on whether or not a question was skipped. Results can be found in Table 2. The average scores reflect only the responses of the 125 children who had both pre- and post-program survey data.

Average scores increased on all five items pertaining to the evaluation question. However, only two indicators of SEL had a statistically significant increase $[p<.001]$ : social awareness and self-management. On the second question measuring social awareness, the average score increased from 2.72 to 3.28. Mean scores on the question addressing self-management ("Can you name three ways to calm yourself down when you're upset?") increased from 2.43 to 2.97 with a score of 3.0 meaning $100 \%$ of children were able to name three. Answers included responses such as "take deep breaths" and "go to the peace center." At the beginning of the year, fewer than 100 of the 125 children could name three ways to soothe themselves, but nearly all of them (124 out of 125) were able to do so when tested at the end of the year. Furthermore, the effect size for the two items mentioned in the multiple response questions 


\section{Social-Emotional Learning}

with significant results was found by dividing the mean difference by the standard deviation (Cohen, 1988). For both questions, the effect size was found to be .50; which is considered a medium effect size (Cohen, 1988). It is recommended that effect sizes be viewed in the context of other research (Durlak et al., 2010) and in a meta-analysis of 75 SEL programs in the United States the average effect size for change in prosocial behavior was .29. Thus, these results show a stronger effect size compared to previous research.

Table 2. Outcomes of Evaluation of SEL Curriculum at EAC

\begin{tabular}{|c|c|c|c|c|c|c|}
\hline Question & $\boldsymbol{N}$ & $\begin{array}{c}\text { Pre } \\
M(S D)\end{array}$ & $\begin{array}{c}\text { Post } \\
M(S D)\end{array}$ & M Diff & $\begin{array}{c}\text { Effect } \\
\text { Size }\end{array}$ & p-value \\
\hline Self-management-1 & 123 & $2.49(1.04)$ & $2.67(1.10)$ & .18 & & .148 \\
\hline Self-management- 2 & 125 & $2.43(1.04)$ & $2.98(0.20)$ & .54 & .50 & .000 \\
\hline Social awareness-1 & 124 & $3.06(0.92)$ & $3.15(0.91)$ & .08 & & .355 \\
\hline Social awareness-2 & 123 & $2.72(0.96)$ & $3.28(0.72)$ & .56 & .50 & .000 \\
\hline Self-awareness & 119 & $2.98(0.95)$ & $3.08(0.96)$ & .10 & & .339 \\
\hline
\end{tabular}

\section{Discussion}

The results of this evaluation indicate ASPs can be an important source of SEL skill-building and provide an ideal setting to supplement SEL skills developed at school. EAC showed initiative in their effort to provide continuity for children receiving SEL curriculum in school as part of the district-wide initiative. As a non-profit with limited funds and personnel, EAC needed creativity and resourcefulness to answer the call for developing new or embracing existing frameworks for providing SEL delivery and evaluation (Durlak et al., 2011; Elias, 2010; Gullotta, 2015; Marzano, 2015). These qualities were demonstrated in how administrators drew from multiple sources to deliver a hybrid SEL curriculum and created an efficient (although untested) evaluation instrument.

Typically, SEL measures are time-intensive (i.e., 10 to 45 minutes per child). The data collection method presented in this article, requires only 5 minutes per student, and is a promising practice for other programs in the future. Children's SEL skills improved after receiving SEL 


\section{Social-Emotional Learning}

curriculum in the areas of social awareness and self-management. Past research found increases in self-management were associated with increased prosocial behavior, lower levels of problem behaviors (e.g., aggression, bullying, delinquency) and improved academic performance (Zins, Bloodworth, Weissberg, \& Walberg, 2004).

This report shows the importance of organizations using available research and resources to craft suitable curricula for the students they serve. EAC's innovative SEL delivery and evaluation can serve as a model or reference for other ASPs with limited resources and can be used to inform future decisions about SEL delivery and evaluation. Research indicates there is no onesize-fits-all approach with SEL, but a good fit between the organization and the implementation and evaluation method is ideal (Denham, 2015; Gullotta, 2015; McKown, 2015), and EAC shows this ideal is possible.

\section{Limitations}

Several limitations must be mentioned. First, children's social-emotional competencies were measured with self-reported rating scales, which provide only a partial understanding of skill improvements (Elliott \& Busse, 2004). Although Crowe, Beauchamp, Catroppa, and Anderson (2011) referred to rating scales as efficient, useful, and the most frequently used measure of assessing children's social-emotional skills, others recommended observation in combination with rating scales (Doll \& Elliott, 1994). Furthermore, past high-validity measures of 'perspective-taking' (CASEL's definition of social awareness; 2003) were task-oriented rather than self-reported (McKown, 2015). In this evaluation, the second measure of social awareness was a task-related vignette which may explain why there was no significant improvement in our first measure of social awareness (a self-report measure). Future evaluations at EAC should include other reporters (e.g., parents, teachers) and vignette-style questions to increase validity.

A second limitation is the inability to imply causality due to the absence of a control group. In this evaluation, EAC administration did not consider withholding the SEL intervention from some children for the purpose of a control group. This would undermine their mission to enhance children's social development.

Lastly, the instrument developed by EAC was based on the CASEL model to assess SEL competencies. Although questions were modeled after other instruments used in conjunction with the CASEL model like SELA and SSIS-PSG (Elliott, Davies, Frey, Gresham, \& Cooper, 2017; 


\section{Social-Emotional Learning}

Elliott \& Gresham, 2007), this instrument was not subject to validity testing. Due to the lack of widespread practical measures of SEL in children, Elias et al. (2015), recommended a "good enough" approach to assessment and advocated for the development of first-generation tools that can be continually revised or supplemented as new techniques develop. Measurement instruments with established validity were considered for this evaluation but required more time and resources than were available. Subsequent replication and factor analysis are needed to further refine this instrument and establish validity.

\section{References}

Abadesco, V., \& Savage, J. (2015). Soul shoppe peace path guidebook. Retrieved from: http://www.onthepeacepath.com/wp-content/uploads/2018/07/peace-path-guide_final.pdf

Afterschool Alliance. (2014). America after 3 pm: Afterschool programs in demand. Retrieved on April 12, 2018 from: http://www.afterschoolalliance.org/documents/AA3PM2014/AA3PM_National_Report.pdf

Belfield, C., Bowden, A. B., Klapp, A., Levin, H., Shand, R., \& Zander, S. (2015). The economic value of social and emotional learning. Journal of Benefit-Cost Analysis, 6(3), 508-544.

Borgers, N., Hox, J., \& Sikkel, D. (2003). Response quality in survey research with children and adolescents: The effect of labeled response options and vague quantifiers. International Journal of Public Opinion Research, 15(1), 83-94. doi:10.1093/ijpor/15.1.83

Boyce, B. C. (2011). The mindfulness revolution: Leading psychologists, scientists, artists, and meditation teachers on the power of mindfulness in daily life. Boston, MA : Shambhala.

Catalano, R. F., Berglund, M. L., Ryan, J. A., Lonczak, H. S., \& Hawkins, J. D. (2004). Positive youth development in the United States: Research findings on evaluations of positive youth development programs. The annals of the American academy of political and social science, 591(1), 98-124. doi:10.1177/0002716203260102

Cohen, J. (1988). Statistical power analysis for the behavioral sciences (2 ${ }^{\text {nd }}$ ed.). Hillsdale, NJ: Erlbaum. Collaborative for Academic, Social, and Emotional Learning [CASEL]. (2003). Safe and sound: An educational leader's guide to evidence-based social and emotional learning programs (Illinois edition). Chicago, IL: Author. Retrieved from https://casel.org/wp-content/uploads/2016/06/safeand-sound-il-edition.pdf

Collaborative for Academic, Social, and Emotional Learning [CASEL]. (2012). Effective social and emotional learning programs: Preschool and elementary school edition (CASEL Guide 2013). Chicago, IL: Author. Retrieved from https://casel.org/wp-content/uploads/2016/01/2013-caselguide-1.pdf 


\section{Social-Emotional Learning}

Coryn, C. L., Spybrook, J. K., Evergreen, S. D., \& Blinkiewicz, M. (2009). Development and evaluation of the social-emotional learning scale. Journal of Psychoeducational Assessment, 274), 283-295. doi: $10.1177 / 0734282908328619$

Crowe, L., Beauchamp, M., Catroppa, C., \& Anderson, V. (2011). Social function assessment tools for children and adolescents: A systematic review from 1988 to 2010. Clinical Psychology Review, 31, 767-785. doi:10.1016/j.cpr.2011.03.008

Denham, S. A. (2015). Assessment of SEL in educational contexts. In J. A. Durlak, C. E. Domitrovich, R. P. Weissberg, T. P. Gullotta (Eds.), Handbook of social and emotional learning: Research and practice (pp. 285-300). New York, NY: Guilford Press.

Doll, B., \& Elliott, S. N. (1994). Representativeness of observed preschool social behaviors: How many data are enough? Journal of Early Intervention, 18(2), 227-238. doi:10.1177/105381519401800209

Domitrovich, C. E., Durlak, J. A., Staley, K. C., \& Weissberg, R. P. (2017). Social-emotional competence: An essential factor for promoting positive adjustment and reducing risk in school children. Child Development 88(2), 408-416. doi:10.1111/cdev.12739

Durlak, J. A., Domitrovich, C. E., Weissberg, R. P., \& Gullotta, T. P. (2015). Handbook of social and emotional learning: Research and practice. New York, NY: Guilford Press.

Durlak, J. A., \& DuPre, E. P. (2008). Implementation matters: A review of research on the influence of implementation on program outcomes and the factors affecting implementation. American Journal of Community Psychology, 41(3/4), 327-350. doi:10.1007/s10464-008-9165-0

Durlak, J. A., Weissberg, R. P., Dymnicki, A. B., Taylor, R. D., \& Schellinger, K. B. (2011). The impact of enhancing students' social and emotional learning: A meta-analysis of school-based universal interventions. Child Development, 82(1), 405-432. doi:10.1111/j.1467-8624.2010.01564.x

Durlak, J. A., Weissberg, R. P., \& Pachan, M. (2010). A Meta-analysis of after-school programs that seek to promote personal and social skills in children and adolescents. American Journal of Community Psychology, 45(3/4), 294-309. doi:10.1007/s10464-010-9300-6

Elias, M. J. (2010). Sustainability of social-emotional learning and related programs: Lessons from a field study. International Journal of Emotional Education, 2(1), 17-33.

Elias, M. J., Leverett, L., Duffell, J. C., Humphrey, N., Stepney, C., \& Ferrito, J. (2015). Integrating SEL with related prevention and youth development approaches. In J. A. Durlak, C. E. Domitrovich, R. P. Weissberg, \& T. P. Gullotta (Eds.), Handbook of social and emotional learning: Research and practice (pp. 33-49). New York, NY: Guilford Press.

Elias, M. J., O'Brien, M. U., \& Weissberg, R. P. (2006). Transformative Leadership for Social-Emotional Learning. Principal Leadership: High School Edition, 74), 10-13. Retrieved from http://libproxy.txstate.edu/login?url=http://search.ebscohost.com.libproxy.txstate.edu/login.aspx ?direct=true $\& \mathrm{db}=$ eue $\& A \mathrm{~N}=507936535 \&$ site =eds-live\&scope =site 


\section{Social-Emotional Learning}

Elliott, S. N., \& Busse, R. T. (2004). Assessment and evaluation of students' behavior and intervention outcomes: The utility of rating scale methods. In R. B. Rutherford, M. M. Quinn, \& S. R. Mathur (Eds.), Handbook of research in emotional and behavioral disorders (pp. 123-142). New York, NY: Guilford Press.

Elliott, S. N., \& Gresham, F. M. (2007). Social skills improvement system (SSIS): Classwide intervention program. Bloomington, MN: Pearson Assessments.

Elliott, S. N., Davies, M. D., Frey, J. R., Gresham, F., \& Cooper, G. (2017). Development and initial validation of a social emotional learning assessment (SELA) for universal screening. Journal of Applied Developmental Psychology, 55(3), 39-51. doi:10.1016/j.appdev.2017.06.002

Gottfredson, D. C., Gerstenblith, S. A., Soulé, D. A., Womer, S. C., \& Lu, S. (2004). Do after-school programs reduce delinquency? Prevention Science, 5(4), 253-266.

doi:10.1023/B:PREV.0000045359.41696.02

Greenberg, M. T., Weissberg, R. P., O’Brien, M. U., Zins, J. E., Fredericks, L., Resnik, H., \& Elias, M. J. (2003). Enhancing school-based prevention and youth development through coordinated social, emotional, and academic learning. American Psychologist, 58(6-7), 466-474.

Gullotta, T. P. (2015). After-school programming and SEL. In J. A. Durlak, C. E. Domitrovich, R. P. Weissberg, \& T. P. Gullotta (Eds.), Handbook of social and emotional learning: Research and practice (pp. 260-266). New York, NY: Guilford Press.

Hurd, N., \& Deutsch, N. (2017). SEL-focused after-school programs. The Future of Children, 271), 95115.

Jennings, P. A., \& Frank, J. L. (2015). Inservice preparation for educators. In J. A. Durlak, C. E. Domitrovich, R. P. Weissberg, \& T. P. Gullotta (Eds.), Handbook of social and emotional learning: Research and practice (pp. 422-437). New York, NY: Guilford Press.

Laughlin, L. (2013). Who's minding the kids? Child care arrangements: Spring 2011. Current Population Reports, pp. 70-135. U.S. Census Bureau, Washington, DC.

Lerner, R. M., Lerner, J. V., Urban, J. B., \& Zaff, J. (2016). Evaluating programs aimed at promoting positive youth development: A relational development systems-based view. Applied Developmental Science, 20(3), 175-187. doi:10.1080/10888691.2015.1082430

Mart, K. A., Weissberg, R. P., \& Kendziora, K. (2015). Systemic Support for SEL in School Districts. In J. A. Durlak, C. E. Domitrovich, R. P. Weissberg, \& T. P. Gullotta (Eds.), Handbook of social and emotional learning: Research and practice (pp. 494-495). New York, NY: Guilford Press.

Marzano, R. J. (2015). Using formative assessment with SEL skills. In J. A. Durlak, C. E. Domitrovich, R. P. Weissberg, \& T. P. Gullotta (Eds.), Handbook of social and emotional learning: Research and practice (pp.336-347). New York, NY: Guilford Press.

McKown, C. (2015). Challenges and opportunities in the direct assessment of children's social and emotional comprehension. In J. A. Durlak, C. E. Domitrovich, R. P. Weissberg, \& T. P. Gullotta 


\section{Social-Emotional Learning}

(Eds.), Handbook of social and emotional learning: Research and practice (pp. 320-335). New York, NY: Guilford Press.

Moffitt, T.E., Arseneault, L., Belsky, D., Dickson, N., Hancox, R. J., Harrington, H., . . Caspi, A. (2011). A gradient of childhood self-control predicts health, wealth, and public safety. Proceedings of the National Academy of Sciences of the United States of America, 108, 2693-2698.

Patti, J., Senge, P., Madrazo, C., \& Stern, R. (2015). Developing socially, emotionally, and cognitively competent school leaders and learning communities. In J. A. Durlak, C. E. Domitrovich, R. P. Weissberg, \& T. P. Gullotta (Eds.), Handbook of social and emotional learning: Research and practice (pp. 438-452). New York, NY: Guilford Press.

Rimm-Kaufman, S. E., \& Hulleman, C. S. (2015). Social and emotional learning in elementary school settings: Identifying mechanisms that matter. In J. A. Durlak, C. E. Domitrovich, R. P. Weissberg, \& T. P. Gullotta (Eds.), Handbook of social and emotional learning: Research and practice (pp. 151-166). New York, NY: Guilford Press.

Sheard, M. K., Ross, S., \& Cheung, A. (2012). Educational effectiveness of an intervention programme for social-emotional learning. International Journal of Multiple Research Approaches, 6(3), 264-284. doi:10.5172/mra.2012.6.3.264

Smith, B., \& Low, S. (2013). The Role of social-emotional learning in bullying prevention efforts. Theory into Practice, 52(4), 280-287. doi:10.1080/00405841.2013.829731

Tolan, P. H., Guerra, N. G., \& Kendall, P. C. (1995). A developmental ecological perspective on antisocial behavior in children and adolescents: Toward a unified risk and intervention framework. Journal of Consulting and Clinical Psychology, 63(4), 579. doi:10.1037//0022-006X.63.4.579

Webster-Stratton, C., \& Herman, K. C. (2010). Disseminating Incredible Years Series early-intervention programs: integrating and sustaining services between school and home. Psychology in the Schools, 471), 36-54. doi:10 1002/pits 20450

Zins, J. E., Bloodworth, M. R., Weissberg, R. P., \& Walberg, H. J. (2004). The Scientific Base Linking Social and Emotional Learning to School Success. In J. E. Zins, R. P. Weissberg, M. C. Wang, \& H. J. Walberg (Eds.). Building academic success on social and emotional learning: What does the research say? (pp. 3-22). New York, NY: Teachers College Press. 